\title{
Waqf as a Socio-Economic Institution
}

\author{
Mohamed Aslam Haneef \\ Professor, Department of Economics, International Islamic University Malaysia
}

\begin{abstract}
Syed Khalid Rashid's lead paper titled 'Potential of Waqf in Contemporary World' is a welcome addition to the growing literature on waqf. This brief writeup focuses more on waqf as a 'socio-economic institution' and to place waqf as the 'third' or voluntary sector of the economy. It will raise some points on a variety of important 'issues' essential for the revival of waqf which, it is hoped, will complement the lead article. In addition, this paper will share findings and draw from a research project (of which the author was a part of) on Waqf and Higher Education (termed as LRGSWaqf), to support arguments put forward.
\end{abstract}

Keywords: Waqf, Welfare, Third sector, Voluntary sector, Higher education, Management of waqf, Waqf Governance, Trusts, Endowments.

KAUJIE classification: E22, E23

\section{Introduction}

About a decade ago when the Centre for Islamic Economics and Policy Research (CIEPR) was being established, 'Waqf as a Socio-economic institution' was chosen as one of the priority research areas. Syed Khalid Rashid, who at that time was Professor at the Ahmad Ibrahim Kulliyyah of Laws (AIKOL), International Islamic University Malaysia, was considered one of the few legal authorities in the area of waqf. It would not be wrong to say that except for a few scattered works, most literature on waqf was either on some fiqh discussion or on administrative/ legal reforms. While Syed Khalid's main work was on legal issues and administration of waqf properties in India, he was also actively involved in proposals for waqf law reforms in Malaysia together with colleagues at AIKOL.

As far as the discussion article (Rashid, 2018) is concerned, any opportunity to have greater discourse is welcomed. Possibly the article tries to cover too many diverse areas and, in the process, suffers from very superficial coverage in some areas. The article has nine sections: section two which is entitled 'waqf and social welfare' would have been more appropriately made a part of the introduction. One would be better off referring to the considerable amount of literature written in this area, especially in the historical context; section three tries to discuss issues in the 'development' of waqf. Many important issues are 
mentioned and some of these will be discussed later. However, a rather 'odd' feature of this section is the relatively extensive discussion on the potential use of blockchain technology in developing waqf. It seems rather misplaced in an overview article where many other more fundamental areas could and should have been given more focus; section four talks of cash waqf and rightly points to its 'revival' in current times; sections five and six address a very important area i.e. the comparison with trusts and the potential contribution of trusts in the development of waqf; section seven discusses the issue of perpetuity of waqf. Rather than have a separate section, it should have been discussed as one of the issues taken up in section three; sections eight and nine address the issue of the role of the state in developing waqf.

The following comments will focus more on looking at the waqf institution as a 'socio-economic institution' and to place waqf as the 'third' or voluntary sector of the economy. It will raise some points on a variety of 'issues' that are hoped will complement the article. Much more detailed arguments are required, and a short commentary cannot do justice to the topic. In addition, this comment will share findings from a research project on Waqf and Higher Education, hereafter termed as LRGSWaqf to support arguments put forward. The current writer was Head of Project 1 in a Long-term Research Grant Scheme (LRGS) Program funded by the Malaysian Ministry of Higher Education. The three-year research program was made up of three projects and involved more than 30 academics from at least eight public universities. As head of Project 1 involving at least 17 academics from four universities, various dimensions of waqf and higher education were covered including historical and comparative studies, developing waqf models, contemporary practices of waqf and evaluation of overall development of higher education waqf. The findings have yet to be published but have been presented in a 'report form' to the Ministry dated January 2018.

\section{Waqf in History}

One of the reasons for the renewed interest in the waqf institution is its vast contribution in the socioeconomic welfare of the community in the past. In $L R G S W a q f$, many areas were analyzed including the historical role of waqf. Although the study was focused more on higher education waqf, some find- ings are universal. For example, rather than being termed 'public goods', waqf was central in providing social goods and social-welfare spending on education, health and infrastructure. For centuries, waqf had been playing a central role for progressing religious, social, cultural, scientific, economic and political aspects of society. The height of waqf achievement was recorded during the reign of the Ottoman Empire, with the establishment of 35,000 waqf or foundations (vakif). These foundations funded public infrastructures and municipal projects including public complexes (kuliyye), mosques, universities, orphanages, bridges, caravansaries, soup kitchens (imarets), fountains, roads and pipeline systems. In the educational system, among the noteworthy contributions of waqf are the world's oldest standing universities such as the University of al-Qarawiyyin in Fez, Morocco (established in 859CE) and the University Al-Azhar in Egypt (established in 975CE) and numerous schools (madāris), universities and libraries all over the globe. Waqf also provided finan-cial support and scholarships to the teachers and students.

Unfortunately, this comprehensive understanding of waqf gave way to it being a narrowly defined 'religious' institution. This misdirection then witnessed waqf properties become limited to building mosques, madāris, orphanages and graveyards. This was supported by another recent study involving respondents from Malaysia, Indonesia and Bangladesh, whereby a majority of respondents could not see the connection of waqf to socio-economic development. Instead, those areas were seen to be the responsibility of either the state or private sector. For example, when the proposal to develop an Integrated Waqf Islamic Microfinance Model (IWIMM) was put forward, many respondents from among clients and even implementers were not convinced that there was a place for waqf in 'socio-economic programs' (Haneef \& Alpay, 2015). Like it or not, to many people the religious-economic divide is ingrained in our current system

How did we end up in this state and how did the waqf institution lose its way? What were the internal and external reasons that saw this rich institution dwindle to its current pathetic state? Unfortunately, the discussion article of Syed Khalid does not cover this very important area sufficiently nor does it even refer readers to this debate and to the vast writings. 
The topic of its decline and current situation requires a much more detailed discussion elsewhere.

\section{Waqf as a 'Religious' Institution}

One of the fundamental challenges in any waqf reform agenda is that it is seen in many jurisdictions as a 'religious' institution. From one angle, there is no problem in this as Islam is a complete way of life. However, the reality is that once this tag is accepted, any understanding and practice of the legal/administrative issues relating to waqf become a discourse in 'religion' and to be more precise, on fiqh matters. The authorities that will decide on the development of the waqf institution would also be the religious authorities of a country, whether it is the Ministry of $A w q \bar{a} f$ as in the Middle East or Ministry of Religious Affairs as found in some countries or the Islamic Religious Councils found in many other Muslim countries, including Malaysia. Any development or reform of waqf then is subject to the capacity and capability of the religious authorities to bring about the required changes. Herein lies the dilemma in many Muslim countries.

In countries like Malaysia where for the last 40 years there have been attempts to reform the zakāh and waqf administration, the pace of these reforms has been very much slower than say, developments in Islamic banking and finance. One reason for the slow pace is the jurisdiction issue. As some have written, Malaysia has a rather unique situation where affairs of religion are concerned - it is an individual 'state' matter. Malaysia has at least 13 'independent' jurisdictions (9 states with Sultans, 4 with Chief Ministers, and Federal Territories of Kuala Lumpur, Labuan and Putrajaya). Hence the Federal government has almost no legal standing in areas of 'religion'. While some may see this separation of powers as a healthy state of affairs - and potentially it can be - the current reality is that it makes the process complicated and slow.

The issue is further compounded when we look at the administrative and management capabilities of 'religious' institutions as a whole. Historically, in many Muslim countries you find a dual jurisdiction system - one for 'secular' affairs and another for 'religious' affairs. It is also well-established through numerous empirical research on the latter that the standards of administrative and management capaci- ties, governance and auditing/reporting leave a lot to be desired. While admirable advances have been made over the last few decades, it is a slow process that requires a new mentality and mindset, one that integrates the traditional with the modern in a right mix. This issue will be further discussed in the following sections.

\section{Management and Investment of Waqf Properties}

There is a need to ensure that waqf management personnel are made up of people who have competence in management and administration. For example, in the case of Malaysia, four decades ago, when reforms in the zakāh and waqf administrations were first being undertaken, it was found that the managers and decision-makers were basically those with high school qualifications and/or those with religious studies diplomas. Today, one sees restructuring and reorganization of these institutions. There are many qualified graduates from economics, business management and accounting working in these institutions. This has been a positive step to ensure that waqf agencies are run professionally.

Rather than limiting the function of waqf to only narrowly defined religious uses, decision-makers and waqf management personnel have to see waqf as part of the economic structure of a country, i.e. as part of the third or voluntary or not-for-profit sector. The potential contribution of waqf is limitless since it is a manifestation of one's giving culture. Again, with reference to LRGSWaqf, it was found that, in general, the role and examples from the practice of endowments in the West especially from the USA and Europe $^{(1)}$ could be used as good examples to convince Muslims of the need to widen their views on the socio-economic role of waqf. Hence, in looking at the potential role of waqf as a socio-economic institution strongly recommended in the religion, we need to learn from at least two sources. Firstly, our own history and examples of the practices of waqf; secondly and may be even more importantly for technical and professional guidance, from the best practices of

(1) The reason why cases from the USA and Europe were quoted is because most research and information on endowments are from the US and Europe. Much more work is needed to study and analyze the not-for-profit sector in all other parts of the world. 
endowments/foundations globally. While historical practices of waqf give us a sense of pride and remind us of our roots and tradition, we have to acknowledge that contemporary benchmarks set up today globally come from the west.

As mentioned by Syed Khalid, waqf properties need to be 'developed' and cannot be left idle. This is because in the principles governing waqf, only the proceeds acquired from its 'investment' can be used while the principal property needs to be intact. However, before any investment can take place, a proper identification of waqf properties needs to be conducted. In many countries, there is yet to be a complete updated register of waqf properties. This must be one priority action if any waqf development plan is to be realised. Some countries have under-taken this such as Malaysia as part of a waqf master-plan ${ }^{(2)}$. Many challenges are identified including lack of registration documents, legal disputes on proper-ties, idle properties and unusable properties. Once this is completed, then comes the challenge of developing those properties. Again this requires best investment and management practices to make sure that these properties are developed in the most appropriate way.

Investment practices require qualified people who have investment expertise, but are also aware of the requirements of Islam. Depending on the nature of the waqf and its purpose, an appropriate investment portfolio should be adopted. More often than not, due to the nature of waqf administration and the lack of proper management systems and professionals, one finds almost no pro-active investment undertaken.

In LRGSWaqf, we undertook a comparative look at the investment practices of 15 institutions internationally (from secondary data) and another 6 public universities in Malaysia that had 'endowment' or investment funds. These assets were mainly in the form of cash funds. For the international 15, in terms of asset allocation, public equities appear to be the most common investment class with most endowment funds over-weighting on them. The key take-

(2) This project was undertaken by the Department of Zakat, Waqf and Hajj in the Federal Government at least 5 years ago. However, until today, the full results have not been made available to all researchers. In addition, since in Malaysia 'religion' is a state matter, not all states gave full cooperation to this study. aways for developing countries in this respect are that firstly, to begin thinking about putting together a portfolio with higher targeted rates of return, and secondly, that such a portfolio would have a diversified makeup comprising various asset classes of investment. It was also found that for the international institutions, about $40 \%$ of the institutions adopted 'active' management of the portfolio (data from others did not allow us to make any conclusion). Rates of return varied from as little as $6.8 \%$ to as high as $20 \%$. This analysis only tells us half of the story as unfortunately, we do not have access to sufficient data to compute risk-adjusted returns. For the 6 Malaysian public universities, in terms of asset allocation, most of the universities in our sample place investment monies in cash and 'fixed income' securities. The majority of the universities resort to passive management of their respective portfolios and have some form of risk management practices albeit limited to simplistic (and somewhat unsophisticated) risk policies with emphasis on the lower end of the risk spectrum. In terms of fund performance, latest 1-year return ranges from $3 \%$ to as high as $8.6 \%$.

The above was the case of university endowments. If waqf for higher education was to be promoted, what portfolio and investment strategy would be adopted? How different would the investment portfolio be from current university endowments? If we see waqf playing a role in many other social sectors such as health or in infrastructure development, what would the portfolio and investment strategy be? Who would be managing and making investment decisions? All of these are very important questions that need to be taken into consideration to ensure that waqf does not remain a slogan, but actually makes a social impact.

\section{Waqf Governance: Accounting, Auditing and Reporting Standards}

Just as in the case of limitations and shortcomings in capacity and capability of expertise in management and investment of waqf, there is a gap as far as governance of waqf institutions is concerned. Using our LRGSWaqf study, two important issues were found in relation to accounting and reporting waqf frameworks for universities. First, the need to be clear on the role of the university in holding waqf asset. Second, and consequent to the first, is the need to differentiate the type of holding. Hence, the re- 
quirement for reporting waqf asset/fund, i.e., special waqf or general waqf. Based on our review of accounting standards, there were no specific guidelines on financial reporting of waqf or even waqf-like organisations (e.g. non-govermental organizations or NGOs) in Malaysia. All NGOs rely on the Registrar of Societies (RoS) for reporting guidelines. However the provision clause is very general, i.e., "what is generally accepted". In relation to this, there is an urgent need for the reporting and accounting governing authority to develop a standard for NGOs and/or charitable organisations. This is very important since numerous studies have indicated that this lack of reporting and hence, transparency, is a key reason why some people do not have confidence in these institutions. In this we have to learn from other countries. There are already some reporting standards such as in Singapore (Charities Accounting Standard - CAS), UK (Statement of Recommender Principles - SoRP) and US (Not For Profit Generally Accepted Accounting Principle - NFP GAAP).

The spirit embodying these charitable organisations are very similar to waqf institutions. However, it was found that the standards of reporting and accounting of waqf institutions leaves a lot to be desired. The fact that these are institutions considered to be 'religious' would give the impression that waqf institutions should have the highest standards of reporting, accounting and auditing. The truth is far from it. Unfortunately 'religious' institutions are not very transparent and seem to mistakenly think that people would trust them just because they are run by 'religious councils' or Ministries of Religion/Awqāf. Unfortunately due to lack of transparency (and also lack of professional management expertise), many people prefer to set up conventional endowments/ foundations where they are able to appoint their own board of trustees ${ }^{(3)}$.

\section{Trusts, Foundations and Endowments - What We Can Learn?}

To me the most interesting section of Syed Khalid's paper is his section on learning from Trusts. He stamps his authority in this area with very clear iden-

(3) This is a challenge in Malaysia since by law, if one uses the word 'waqf', it has to be governed by the religious councils and they would be given sole mutawalli status. They are able to appoint agents or managers, but the State Islamic Religious Councils (SIRCs) have the sole power of trusteeship. tification of the problems and puts forward very practical steps to find the solutions. I hope to add to his arguments by sharing some challenges faced on this issue from our LRGSWaqf study.

\subsection{Separating Religious Waqf from Socio- Economic Waqf}

At first glance, some may oppose this suggestion as this may seem to be promoting and continuing the dualistic system found in most Muslim countries, i.e. a 'secular' system side by side with a 'religious' system. In fact, some may say this is an endorsement of secularism as a governing ideology. While in an ideal world, one should not have this apparent dichotomy, in the real world this division still exists and does affect the development of waqf as a socio-economic institution. Our previous elders may have tried to protect the institution of waqf during colonial times by making it one of the items that fell under the jurisdiction of 'religion' during colonial times and hence, came under the control of the religious authorities rather than be under the secular western colonial system. However, today after decades of independence and attempts at comprehensive Islamic reforms, it is these very Islamic institutions that require reforms themselves.

Administration of Sharī ah courts, zakāh and waqf institutions and all legal frameworks and laws together with the human resources related to these areas are still struggling with the demands for reform. While efforts to reform our economic and financial systems face many challenges related to the 'Islamization' agenda, our traditional institutions face the challenge of 'relevantization', i.e. how to make these institutions function effectively in modern times. While the former is dominated by generally secularwestern educated professionals, hence requiring exposure to our Islamic legacy and worldview, the latter is almost wholly governed by 'traditionally trained' individuals, hence requiring exposure to modern knowledge and science.

Therefore, the proposal of Syed Khalid to make this separation could be seen as something of a 'transition' stage in order to allow waqf to play its intended socio-economic role in society without encroaching into existing waqf administration while it is undergoing its own reforms according to its own pace. Possibly, some realistic timeline as well as 
some performance indicators should be set to ensure that the reforms make progress. This is certainly something that potential donors cum wäqif will look for. This transitional separation may even be reserved for new waqf endowed if that would be more acceptable.

\section{2 'Sacredness' of the term Waqf and Resistance to Adopting Practices of Contemporary Endowments/Foundations}

In the course of the LRGSWaqf study, there were opinions (possibly a vociferous minority) that tried to insist that only the term waqf should be used in attempts to find alternative sources of funds for universities. Examples of past Muslim civilization and historical accounts of the success of waqf were given to support this argument. At times, it seemed as if the term waqf was itself having some 'sacred' status! Attempts by universities that had previously established very successful endowments, including endowments that met all the requirements of the Shari' ah were considered to be 'second-best' and even unacceptable. To them, there was no such thing as Islamic endowment just as there was also no sense in talking about an Islamic bank. This very shallow mindset, understanding of the institution and its functions, and obsession with terms per se, are a major obstacle to developing the waqf institution as a $21^{\text {st }}$ century socio-economic institution. The attempt to be exclusive and to claim complete uniqueness is worrying.

The idea of separating socio-economic waqf from religious waqf would be a very practical and non-intrusive way to allow for reforms to take place while at the same time, allowing waqf to play a more significant role in socio-economic development efforts. The existing power structures that govern religious waqf should be allowed to move at their own pace. On the other hand, waqf for socio-economic efforts would have to be bound by not only existing laws of trust but also to the Shari ah. This can be clearly stated at the beginning and, if needed, amendments to laws of trust in a particular country can be made to allow for trusts and endowments to meet all requirements of the Sharī ah.

\subsection{Applying Best Practices for Waqf governance}

By allowing for the transitional separation of socioeconomic waqf from religious/traditional waqf, the former could then be subject to all the best practices standards and benchmarks of global benchmarks in addition to Sharī' ah benchmarks. These awq $\bar{a} f$ would then be subject to governance standards in management, investment, accounting, auditing and reporting that would give full confidence to the ummah that these institutions are well run and pro-active in achieving its intended objectives. Once religious waqf have made all the necessary reforms at their own pace, they could choose to adopt these practices too. At that point in time, whether the waqf use was for the building of a mosque or for establishing and running a training center for computer skill enhancement, they would both be equally Sharī ah governed as well as effectively run and managed.

\section{Conclusion}

The institution of waqf/endowment can play an important role in the transformation of the ummah. Historically, waqf played a central role in the provision of social goods and services, including in education, health, utilities and infrastructure. It is imperative that more research is undertaken in this area. In addition, many countries today have an effective endowment/foundation sector that is contributing effectively to socio-economic development of communities globally. We must learn from them. Muslim countries have recently started to undertake reforms to develop waqf/endowments as a source of alternative funding as well as provision of social goods and services. While much research has been done, numerous conferences have been organized, it is the implementation of these ideas for reform that has been moving at a snail's pace. Political will is needed to push reforms in waqf development. One good strategy to initiate and push these reforms forward is to allow a 'separation' of 'religious waqf' and 'socioeconomic waqf', the former being maintained under the existing authorities while the latter is entrusted to a more dynamic and professional board of trustees, but with accountability to all stakeholders. 


\section{References}

Haneef, M. A., \& Alpay, S. (Eds.). (2015). Integration of Waqf and Islamic Microfinance for Poverty Reduction: Case Studies of Malaysia, Indonesia and Bangladesh. Ankara, Turkey: SESRIC.
Rashid, S. K. (2018). Potential of Waqf in Contemporary World. Journal of King Abdulaziz University: Islamic Economics, 31(2), 53-69.

Mohamed Aslam Haneef is currently Professor at the Department of Economics, International Islamic University Malaysia. He received his $\mathrm{PhD}$ from the School of Development Studies, University of East Anglia, UK and also holds a Masters of Economics from the University of Malaya and Bachelors of Economics (Hons.) from the IIUM. He teaches economics and Islamic economics at both the undergraduate and graduate levels as well as in executive MBA and Post-Graduate Diploma programs. He has published books and articles and conducted research in various areas of Economics and Development Studies and is also involved in numerous public and private executive training programs, specializing in Islamic economics and contemporary development issues. Currently, he is the Director of the Centre for Islamic Economics, IIUM and a member of the editorial team for the International Journal of Economics, Management and Accounting.

E-mail: mdaslam@iium.edu.my 


\title{
الوقف كمؤسسة اجتماعية واقتصـادية
}

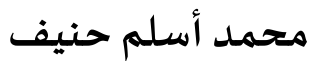 \\ أستاذ، قسم الاقتصاد، الجامعة الإسلامية العالمية، ماليزيا
}

المستخلص. تعتبر ورقة سيد خالد رشيد الرئيسة بعنوان "إمكانيات الوقف في العالم المعاصر"

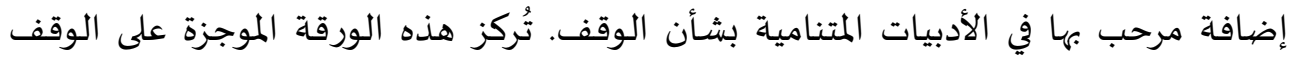

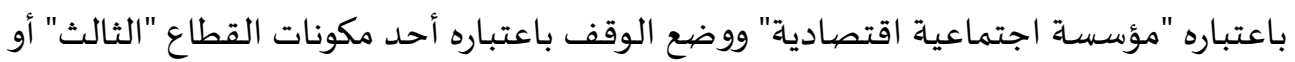

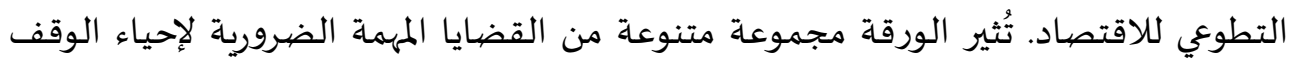

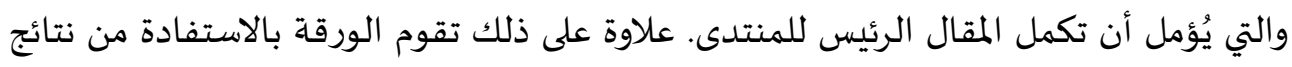
مشروع بحثي (كان المؤلف جزءًا منه)، عن الوقف والتعليم العالي لدعم الحجج المقدمة في الورقة. الكلمات الدَّالة: الوقف، الرعاية الاجتماعية، القطاع الثالث، القطاع التطوعي، التعليم العالي،

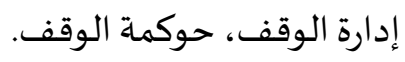

